Published 2011in: Luschützky, Hans-Christian \& Franz Rainer (eds.) 2011. Agent-noun polysemy in a cross-linguistic perspective. Special issue of Sprachtypologie und

\title{
Polysemous Agent Nominals in Kambaata (Cushitic) ${ }^{*}$
}

\begin{abstract}
Kambaata has a morpheme -aan with which agent nominals can be derived from verbs and nouns. The present article discusses, firstly, the morphological and syntactic characteristics of -aan nominals and the specific problem of which word class they should be assigned to. Secondly, it is shown that the -aan morpheme is multifunctional. Apart from agent nominals, it is used to derive instrument, place and patient nominals.
\end{abstract}

\section{Introduction}

Kambaata belongs to the Cushitic branch of the Afro-Asiatic language phylum, more precisely to the Highland East Cushitic (HEC) language group. The hitherto little documented language is spoken by more than 600,000 speakers in an area approximately $300 \mathrm{~km}$ south-west of the Ethiopian capital Addis Ababa. The language has a robust noun-verb distinction and a (sub-)word class of adjectives. ${ }^{1}$ Kambaata is strictly suffixing and has a rich verbal and nominal morphology. One of its derivational morphemes, the agentive morpheme -aan, productively generates agent nominals on the basis of verbs. In the present article, the formal features (section 2) as well as the meaning and use of -aan nominals (section 3) are discussed. In a language without a documented history, agent nominals can only be analysed in a synchronic perspective. ${ }^{2}$ The present work is intended to supplement the vast literature on agentive derivations that is predominantly concerned with Indo-European languages. This study is based on a corpus of spontaneously produced recorded data, elicited data and data from written sources. In addition, published works are consulted. First examples for derived agent nominals in Kambaata are given in LESLAU $(1952,1956)$, HUDSON (1976) and SHELEME (1989). Though sketchy, these previous works already point to some of the important features of

* Research for this paper was supported in part by grants from the Deutsche Forschungsgemeinschaft (DFG) and by a La Trobe Post-doctoral Research Fellowship; this support is gratefully acknowledged. I am indebted to my consultants Tessema Handiso and Deginet Wotango. Thanks are also due to Abeba Matewos, Getahun Hellebo, Berhanu Erango, Getahun Jorga, Ermias Hirigo and Mulugeta Eyoel for replying to my questionnaire. I am grateful to Gerrit J. Dimmendaal and an anonymous reviewer for valuable comments on an earlier version of this paper.

1 As argued in TREIS (2008: 81-97), Kambaata has four open word classes: nouns, verbs, attributes (with the sub-word classes adjectives, numerals and demonstratives) and ideophones/interjections.

2 The earliest lexical account of Xambaaro, a Kambaata dialect, is Borelli (1890). The very first grammatical information on Kambaata is provided in CERULLI (1925) and MORENO (1939). 
the -aan morpheme and its derivates. All HEC languages share a cognate "agentive suffix" (HUDSON 1976: 273f).

\section{Form}

The Kambaata agent nominal has the following morphological structure:

\section{STEM-aan-NUMBER-CASE(-GENDER)}

Though deverbal agent nominals are much more common (1), it was noted as early as in LESLAU (1952:351) that -aan is also attached to nominal bases (2). ${ }^{3}$

(1) kiil-aan-ch-ú 'magician' (L52: 351) $<$ kiil- 'do magic'

kaas-aan-ch-ú 'planter' (K8: 8) < kaas- 'plant'

amma'nn-aan-ch-ú 'believer' < amma'nn- 'believe'

raga'-aan-ch-ú 'heir' < raga'- 'inherit'

zaakkoot-aan-ch-ú-ta' 'alcohol trader (F)' < zaakkoot- 'trade alcohol'

(2) lokk-aan-ch-ú 'pedestrian' (L52: 351) < lokk-á-ta 'foot'

qomaax-aan-n-ú 'lepers' (K8: 47) < qomaax-á 'leprosy'

maz-aan-ch-ú 'wounded person' (K5: 9) < maz-á-ta 'wound'

Verbal bases of agent nominals may be bare roots (3) or extended verbs, i.e. causative (4-5), middle (6), passive (7) or reciprocal stems (8). In rare cases, agent nominals are derivates of compound stems (9). Complex nominal stems are not attested as the input of the agentive derivation.

(3) ros-aan-ch-ú 'student' < ros- 'learn'

(4) ros-is-aan-ch-ú 'teacher' < ros-is- 'cause to learn'

(5) il-siis-aan-ch-ú-ta 'midwife' (F) < il-siis- 'cause to give birth'

(6) uиcc-aqq-aan-chú 'beggar' < uucc-aqq- 'beg for one's benefit'

(7) xa'mm-am-aan-ch-ú 'person questioned' < xa'mm-am- 'be asked' (K8: 55)

(8) beeqq-am-aan-ch-úu 'participant' < beeqq-am- 'participate' (K8: 28)

(9) giir-qas-aan-ch-ú 'bonfire' < giir-á-ta 'fire' + qas- 'pierce'

3 The morpheme -aan is only rarely attested on adjectival stems (Treis 2008: 268, 282). Kambaata thus confirms DRESSLER's cline of the preferred bases of agent noun formation: verb $>$ noun $>$ adjective (DRESSLER 1986: 524). Due to the lack of reliable data, however, de-adjectival derivates are excluded from the present analysis.

4 Kambaata examples cited from earlier works (LeSLAU 1952, 1956; SHELEME 1989; HUDSON 1976, 1989; BERHANU 1986) are adjusted to the official Kambaata orthography (MAATEWOOS 1992; TREIS 2008: 73-79) to enable easier comparison of the examples. In addition to this, stress is marked and, if necessary, the transcription of these data is corrected.

5 The base noun is an Amharic loan. Interestingly, Amharic \$oom qwämat'a designates the patient ('leper'), while the disease is referred to by the derived noun \$oom qwamt'anna 'leprosy' (KANE 1990: 708f) 
The agentive morpheme is obligatorily followed by at least two morphemes, the first one being a number morpheme. The singulative morpheme -ch marks singular reference. The form with a doubled stem-final consonant is used for plural reference (10). ${ }^{6}$ Number morphemes precede case suffixes, e.g. the morpheme $-\dot{u}$, which marks the accusative on masculine agent nominals. ${ }^{7}$ When the agent nominal has a feminine referent, the gender marker - $t a$ is added in the accusative; see (5).

(10) mogga'-aan-ch-ú(-ta) M.SG (F.SG) 'thief' / mogga'-aan- $\underline{n}$-ú PL 'thieves'

Agent nominals share morphological and syntactic features with nouns, verbs and adjectives. As phrasal heads, agent nominals inflect like nouns and distinguish as many case forms as the latter do: accusative, nominative, genitive, dative, ablative, instrumental-comitative-perlative, locative and oblique (TREIS 2008: 103). In (11), the first agent nominal is ablative-marked as the head of the standard NP, the second agent nominal is nominative-marked as the head of the subject NP. Like nouns, agent nominals can be modified by genitive nouns (12) and adjectives (13).

(11) $x a h-i \quad$ dimb-aan-n-íichch seel-i dimb-áan-ch-u woyy-áno word-M.GEN be:drunk-AAN-PL-M.ABL beer-M.GEN be:drunk-AAN-SG-M.NOM be:better-3M.IPV A beer drunkard is better than word drunkards. [Proverb]

(12) mixaad-i (M.GEN) shiinsh-aan-ch-ú 'griddle wiper' < shiinsh- 'wipe' haraqé (F.GEN) ag-aan- $n$-ú 'spirits drinkers' < ag- 'drink'

maganzeeb-ó (F.GEN) moos-aan-n-úu 'patients of the rainbow [disease]' < moos- 'be(come) sick'

(13) woyy-á lallab-aan-ch-ú 'better orator' < lallab- 'speak in public' hoolam-á zazzal-aan- $n$-ú 'many traders' < zazzal- 'trade'

Although they are to a certain extent noun-like, deverbal agent nominals reflect ("inherit") the argument structure of their verbal bases. Like verbs, they are able to govern objects (14). Though commonly modified by adjectives (13), they may also be modified by adverbs (15).

(14) maal-á (ACC) it-áan-ch-o (K4:33) '[you] meat eater' oddishsh-á-ta (ACC) gob-aan-ch-ú (H89: 148) 'tailor' [lit. "clothes sewer"] jeechch-ú-ta (ACC) abbis-aan-ch-ú (K4: 18) 'punctual person' [lit. "time respecter"]

$$
\begin{array}{rll}
{[\ldots] \text { danáam-o-ga }} & \text { xawaaqq-aan-ch-ú } & \text { ass-íi dand-áno } \\
\text { good-M.OBL-ADV } & \text { speak-AAN-SG-M.ACC } & \text { do-M.DAT be:able-3M.IPV }
\end{array}
$$

[A sound rhetorical education] can produce a good [lit. "well"] speaker.

Deverbal agent nominals are even capable of governing more or less elaborate subordinate clauses; see the converb clauses preceding the agent nominals in (16-18). ${ }^{8}$

6 K'abeena and Alaaba, Kambaata's closest relatives, have slightly different plural forms: -aan-ú in K'abeena (CRASS 2005: 73) and -aan-ú-ta in Alaaba (SCHNEIDER-BLUM 2007: 147).

7 The accusative case form is also the citation form.

8 Consult SCHNEIDER-Blum (2007: 147, ex. 411) for an Alaaba example in which an agent nominal is modified by a converb. 
Rather than just taking verbal stems as its basis, the -aan morpheme can be considered as being attached to a complete (more or less complex) verb phrase (cf. DRESSLER 1986: 522), including objects and adverbial constituents such as converb clauses, as indicated by the square brackets in the first lines of (16)-(18).

$$
\begin{aligned}
& \text { [maqées-s it]-áan-ch-o (K4: 33) } \\
& \text { do:with:force-2SG.PCO eat-AAN-SG-M.OBL } \\
& \text { [you] forceful eater [lit. "forcefully eater"] }
\end{aligned}
$$

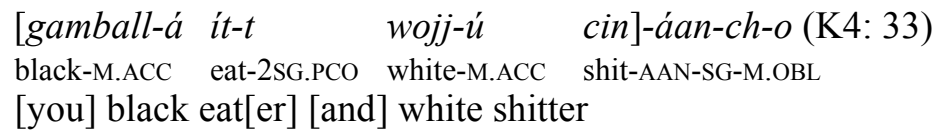

$$
\begin{array}{lll}
\text { [ga"-aqq-án- } t & \text { beeqq-án- } t & i t \text { ]-áan-ch-o }(\mathrm{K} 4: 33) \\
\text { call-MID-PASS-2SG.PCO } & \text { divide.MID-PASS-2SG.PCO } & \text { eat-AAN-SG-M.OBL } \\
\text { [you] assemble[r], share[r] [and] eater } &
\end{array}
$$

It is not yet clear what makes speakers prefer a [Complement V-]aan-ch-ú (as, e.g., in (14)) to a [Genitive] [V-]aan-ch-ú construction (as, e.g., in (12)). Whereas for certain agent nominals, all speakers interviewed unanimously voted for a genitive modifier (e.g. in the case of qabal-é (F.GEN) gashsh-aan-ch-ú 'qäbäle ruler', lit. "ruler of a qäbäle") ${ }^{10}$ or an accusative complement (e.g. in the case of heess-á (M.ACC) kul-aan-ch-u' 'story teller'), in many other cases, some informants preferred the complement construction, some the genitive construction, and others even considered both to be equally possible (e.g. in the case of oddishsh-á-ta (F.ACC) / oddishsh-á (F.GEN) gob-aan-ch-ú 'tailor', lit. "clothes sewer / sewer of clothes"). ${ }^{11}$

Note, however, that agent nominals derived from nouns (2) are unable to govern complements; they may only occur with a genitive modifier, as the -aan derivate of the noun zeem-á-ta 'herding, tending' given below in (19) is intended to show.

$$
\begin{aligned}
& \text { lal-i zeem-aan-ch-ú } \quad \text { *lal-ú zeem-aan-ch-ú } \\
& \text { cattle-M.GEN herding-AAN-SG-M.ACC } \\
& \text { cowherd [lit. "herdsman of cattle"] }
\end{aligned}
$$

Up to this point, agent nominals seem to be nouns that have inherited part of the argument structure of their verbal bases. In contrast to this first impression, I will argue in the following that agent nominals are probably best considered to belong to the (sub-)word class ADJECTIVE - in spite of their nominal inflectional behaviour and in spite of their partially verbal (internal) syntax.

When carefully reading through the translations of agent nominals in earlier publications, first hints at the adjectival features of agent nominals can be detected: some of them are translated as adjectives. See, for instance, qit-aan-ch-ú 'jealous' (LESLAU 1956: 988) < qit- 'be(come) jealous' and dimb-aan-ch-ú 'drunk' (HUDSON 1989: 314) < dimb- 'be(come) drunk'. The evidence that agent nominals indeed

9 The vivid examples in (16)-(18) are verses from a eulogy for a deceased hyena.

10 Smallest administrative unit in Ethiopia: Amharic $\boldsymbol{\$} \cap \mathbf{b}$ qäbäle, Kambaata qabal-i-ta.

11 The verbal bases of the agent nominals given above, gashsh- 'rule', kul- 'tell' and gob- 'sew', do not differ with respect to their argument structure; they all govern accusative complements. 
share formal features (and not only the translation in the meta-language) with members of the word class ADJECTIVE is provided in (20), in which -aan derivates are not used as phrasal heads but as modifiers. Unlike nouns, but in the same way as members of the word-class ADJECTIVE, agent nominals display gender and case agreement with their head noun. This type of agreement is one of the defining features of the word class ADJECTIVE (TREIS 2008: 88-93). Like underived adjectives, agent nominals differentiate three cases (accusative, nominative and oblique: (20)) and two genders (masculine (20) and feminine (21)) when used attributively. ${ }^{12}$

(20) xumm-aan-ch-ú (M.ACC) agg-á (M. ros-áan-ch-u (M.NOM) jáal-u (M.NOM) 'school friend' (K8: 21) qaaxx-áan-ch-o (M.OBL) sa'-ii (M.DAT) 'for the greedy cow' ${ }^{13}$

(21) moos-aan-ch-úta wees-íta úl-tee od-áan become:sick-AAN-SG-F.ACC enset:plant-F.ACC touch-3F.PVE.REL tool-F.ICP with a tool that has been in contact with sick enset plants (K8: 31)

Unlike adjectives, modifying nouns invariantly occur in the genitive case, irrespective of the case of the head noun; they don't agree in gender either (22).

(22) $a z-o ́$ (F.GEN) $s a$ '-á (M.ACC) 'dairy cow' [lit. "cow of milk”] $a z-o ́$ (F.GEN) sá'-u (M.NOM)

The case morphology of modifying agent nominals is identical to that of other modifying adjectives (TREIS 2008: 256). Apart from this, agent nominals also share a syntactic peculiarity with adjectives: the syntactic and semantic head noun of an adjective (mann-á in (23)-i) can be removed from its usual position and instead be added as a genitive modifier; the adjective thus becomes the syntactic head of the NP as in (23)-ii. The dependency relation is reversed (cf. Malchukov 2000) in order to foreground the adjective. Modifiers other than adjectives and agent nominals cannot be foregrounded in this way. Example (24) illustrates the use of agent nominals in such a reversed construction.

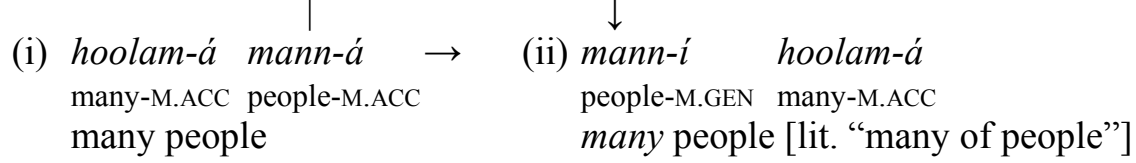

(24) iz-eechch-ó mogga'-aan-ch-úta nubaachch-í qophphan-aan-ch-ú bride-SG-F.GEN steal-AAN-SG-F.ACC old:person.SG-M.GEN lie-AAN-SG-M.ACC [Beware of] a bride that steals and an old man that lies [lit. "a thief of a bride and a liar of an old man"]. (Proverb) (BERHANU 1986: 14)

12 The OBL case form of an adjective modifies nouns that are neither ACC nor NOM but, for instance, DAT. (Note that it is impossible, as suggested by a reader, to analyse the agent nominals in (20) as being in apposition to their head nouns. If they were in apposition, they would follow the (semantic) heads and have exactly the same case range as nouns. As modifiers, however, they precede the head nouns and inflect like adjectives.)

13 The agent nominals in (20) are based on xumm-á 'peace', ros- 'learn' and qaaxx- 'be greedy'. 
Consequently, it would be misleading to speak about agent nouns but much more appropriate to speak about agent adjectives in Kambaata. ${ }^{14}$ Agent derivates and non-derived adjectives have identical inflection potential. As attributes, they agree obligatorily in case and gender with their head noun. Furthermore, they can be used as phrasal heads without being subjected to further morphological operations (25). As phrasal heads, they distinguish all the eight case forms for which nouns inflect.

$$
\begin{aligned}
& \begin{array}{l}
\text { aakiim-iichch (N) / hoga'-aan-ch-íichch (AAN) / hiil-iichch (A) aaqq-éemm } \\
\text { doctor-M.ABL }
\end{array} \text { farm-AAN-SG-M.ABL } \\
& \text { bad-M.ABL receive-1SG.PVE }
\end{aligned}
$$

I received it from the doctor / from the farmer / from the bad one.

With respect to their syntactic behaviour two types of agent nominals must be distinguished: deverbal and denominal -aan derivates. Deverbal derivates are able (i) to govern complements and be adverbially modified (like their bases) or (ii) to be modified by genitive nouns and adjectives. For members of the denominal group only option (ii) is possible.

\section{Meaning and Use}

\subsection{Agents}

So far, I have been speaking about agent nominals, but, admittedly, this term is not appropriate if the polysemy of -aan derivates is taken into account. SHELEME (1989: 33) is the first to state that the Kambaata -aan morpheme is multifunctional and a derivational device for both agents and instruments. Three of his four illustrative -aan examples are instruments, e.g. saqal-aan-ch-ú 'hook' < saqal- 'hang'. Though it is not pointed out explicitly by HUDSON, two -aan derivates that do not refer to agents can also be found in his publications. They refer to an instrument (gamax-aan-ch-ú 'rasp, file' < gamax- 'whet, sharpen' (1989: 317)), and a patient (usur-aan-ch-ú 'prisoner' < usur- 'tie' (1976: 273)). Therefore, a closer look at the meaning of the so-called agent nominals is necessary.

Most of the -aan nominals indeed designate the agent of an action. Often the referent is to be interpreted as a habitual or professional agent (26).

(26) bolx-aan-ch-ú 'show-off' < bolx- 'be(come) proud; boast'

gaaz-aan-ch-ú 'warrior, soldier' < gaaz- 'wage war'

hoga'-aan-ch-ú 'farmer' < hoga'- 'plough'

tukk-aan-ch-ú 'guard, watchman' < tukk- 'guard'

tum-aan-ch-ú 'smith' < tum- 'pound'

14 In this article, the term "agent noun" is consistently avoided. Instead, the more general term "agent nominal" is used. The term "nominal" is meant to refer to a kind of "super" word class encompassing all case-inflecting words (nouns, pronouns, adjectives, numerals, demonstratives). While there is no indication in the grammars of K'abeena (CRASS 2005) and Alaaba (SCHNEIDERBLUM 2007) that the derivates in these languages have adjectival characteristics, KAWACHI also faces a categorisation problem for -aan derivates in Sidaama, which are shown to "have characteristics of both nouns and adjectives" (2007: 318). 
However, in contrast to what SCHNEIDER-BLUM states with respect to -aan derivates in Alaaba, viz. that they do not refer to agents of "specific" actions but only to those of "habitual" actions (2007: 148), agent nominals in Kambaata are attested to designate habitual / professional agents and occasional / temporary / one-time agents. Depending on the context, a xa'mm-aan-ch-ú ( $<x a^{\prime} m m$ - 'ask') may be a person asking at a certain point in time or a professional interviewer. And although dimb-aan-ch-ú (< dimb- 'be(come) drunk') often designates a habitual drunkard, it may also be used to refer to a temporarily drunk person. Temporary readers may be denoted by anabbab-aan-n-ú (< anabbab- 'read') and temporary swimmers by waachch-aan- $n-u$ ' (<waachch- 'swim'). People who happen to encounter an argument and who intervene and mediate spontaneously are referred to as araars-aan$n-\dot{u}$ 'interveners' (< araars- 'intervene'). This means that -aan derivates may be used deictically (RYDER 1999: 282f): in a certain speech situation, nameless persons can be picked out of a group of possible referents by alluding to their present activity (e.g. araars- 'intervene') which is in contrast to the activities (e.g. quarrelling, not intervening) of other participants of the speech situation.

The examples in (27) illustrate that the notion of agent is problematic when describing the semantics of -aan derivates. Apart from prototypical (intentional) agents, experiencers are also referred to by -aan derivates. Most of the experiencer nominals are based on inchoative-stative verbs.

(27) maccar-aan-ch-ú 'crazy person' < maccaar- 'be(come) crazy'

guruur-aan-ch-ú 'miser, skinflint' < guruur- 'be(come) stingy, miserly' moos-aan-ch-ú 'patient, sick person' < moos- 'be(come) sick' saal-aan-ch-ú 'shy person' < saal- 'be(come) shy'

The referents of agent nominals are overwhelmingly human, though non-human agents are also attested. An example of the latter is zaaz-aan-ch-ú-ta $(<z a a z-$ 'flow'), a term denoting a plant species. The creeping ("flowing") growth gave the spice plant its name.

\subsection{Instruments and Containers}

The Kambaata agentive derivation generates instrument-designating terms.

(28) gamax-aan-ch-úu 'rasp, file' [lit. "sharpener"] < gamax- 'whet, sharpen' saqal-aan-ch-ú 'hook' [lit. "hanger"] (S89: 33) < saqal- 'hang' shiinsh-aan-ch-ú 'wiper' < shiinsh- 'wipe' xaaf-aan-ch-ú 'pen' [lit. "writer"] < xaaf- 'write'

Agent-instrument polysemy probably also characterizes the -aan derivation in other HEC languages; it is at least attested in Sidaama, Alaaba and Burji. Besides many derived agents (e.g. uucc'-akk'-aan-c-ú(beggar'), one Alaaba instrument derived with -aan, namely laakk'-aan-c-ú 'mirror' (<laakk'- MID 'see oneself'), is listed in SCHNEIDER-BLUM (2007: 148). ANBESSA's description of nominal derivation in Sidaama shows that the morpheme -aan is used to derive agents as well as instruments; see hat'ar-aančo 'butcher' (< hat'ar- 'butcher') and fey-aančo 
'broom' (<fey- 'sweep') (2000: 67). ${ }^{15}$ ROBA DAME \& WEDEKIND's Burji dictionary contains the following derived instrument: k'un-aancoo 'small stone for pounding' ( $<$ k'un- 'pound') (2008: 54).

Containers (dishes, pots, etc.), plates and boards are conceptually located in the transitional area between instruments and places (DRESSLER 1980: 112f). Products are produced or kept with / by them as well as in or on them. Container (29) is derived from a causative verb, (30) is denominal, and (31) based on a noun-verb compound.

(29) qeess-is-aan-ch-ú-ta 'dish with / in which cheese (qeess-á) is produced' $<$ qeess-is- 'produce cheese'

(30) mooc-in-aan-ch-ú-ta 'dish with / in which the acidic juice (mooc-á) that one squeezes out of enset pulp is collected ${ }^{16}$

(31) ang-a'll-aan-ch-ú 'vessel used to warm water for washing' < ang-á-ta 'hand' plus $a a^{\prime} l l-$ 'wash (MID)'

The bases of some container nouns do not (or no longer) exist in Kambaata (32).

(32) koor-aan-ch-u' 'pot with / in which butter is melted' (<*koor-) wonshir-aan-ch-ú-ta 'large jar in which, e.g., beer is stored' ( $<*$ wonshir-)

Agent-instrument/place polysemy is possibly also a feature of the -aan derivation in K'abeena (HEC), as one example from CRASS (2005: 74) leads one to assume: the nominal $k$ 'amb-aan-č-u 'device [board, mat, leaf?] put underneath enset pulp when it is being kneaded ${ }^{\prime 17}$ is based on the verb $k$ 'amb- 'knead'. Sidaama ofol-aan$\check{c}$-o 'seat' (<ofol- 'sit') is another example for a place noun generated by the -aan derivation (KAWACHI 2007: 318).

\subsection{Patients}

Besides agents and instruments, the -aan derivation generates patient nominals. Two types of patient nominals should be distinguished: (i) derivates based on passive verbs and (ii) derivates based on non-passive verbs. The first pattern is quite productive and also attested in K'abeena (CRASS 2005: 74). The input of the derivational pattern in (33) is a verbal stem extended with the morpheme -am. The derivate refers to what the subject of the verb would refer to.

(33) $g a$ "-am-aan-ch-ú-ta 'consonant' [lit. "one that is called"] (KXS: 4) $<g a$ "am- PASS 'be called' < ga"'- 'call'

$x a$ 'mm-am-aan-ch-úu 'person questioned' (K8: 55) < xa'mm-am- PASS 'be asked' < xa'mm- 'ask'

The passive-based derivates in (33) may lead one to take a syntactic approach into account. Instead of linking the -aan nominals to the semantic roles (agent, experi-

15 As in Kambaata, the Sidaama formative -aančo consists of the derivational morpheme -aan, the singulative marker $-\check{c}$ (Kambaata: $-c h$ ) and a case marker $-o$.

16 The function of the additional morpheme -in is not known.

17 German translation in the original: 'Unterlage zum Kneten von Ensetemark' (CRASS 2005: 74). 
encer, instrument, patient) that their referents play if expressed as arguments of their related verbs, one could consider correlating them with the syntactic functions which their referents occupy if expressed as arguments of their verbal bases. Most nominals discussed so far can occur, in principle, as subjects of their base verbs: agents, experiencers, instruments (with restrictions) ${ }^{18}$ and (if the verb is passive) patients. Thus one could call the -aan derivates "subject nominals". This syntactic generalization is, however, weakened by a considerable number of -aan nominals which never serve as subjects of their base verbs. Among these examples which are "disruptive" for the syntactic account are the containers in section 3.2 above and the type (ii) patient nouns. Though based on active verbal stems, some Kambaata -aan derivates designate the patient of the action encoded by the verb, or, speaking in syntactic terms, they refer to what the direct object of the verb would refer to.

(34) nugguss-aan-ch-ú(-ta) 'circumcised boy (girl)' (*'circumciser') < nugguss'circumcise'

tuph-aan-ch-ú-ta 'bung, stopper (of water pot)' < tuph- 'plug into, stick into' haankur-aan-ch-ú-ta 'product which is steamed on the griddle' < haankur'steam'

Type (ii) patient nominals are encountered in texts but rarely found in elicited data. In Kambaata, they seem to be the least productive type of -aan nominals, at least in the common language. ${ }^{19}$ Type (ii) patient nominals are absent from the descriptions of other HEC languages, with the possible exception of one entry in the Burji dictionary: nakk-aancoo 'a handful' (< nakk- 'grasp') (ROBA DAME \& WEDEKIND 2008: 66).

The interpretation of -aan derivates as referring to events can probably be excluded for Kambaata. The only example pointing to such an interpretation, shameell-aan-ch-ú 'cry of encouragement' (HUDSON 1989: 337), was unknown to my informants. The basis of the assumed Kambaata word could not be determined.

\subsection{Ambiguities and Competing Mechanisms}

A look at the corpus reveals that the majority of -aan derivates are attested in any one of the interpretations (agent, instrument, place, or patient) but rarely in more than one. The possible interpretations are almost "complementarily distributed" some derivates always or usually occur as agents, others as instruments. Despite this, speakers (and listeners) have a certain interpretational freedom, and ambiguities might arise, as informants confirm. First evidence for competing interpretations is found in the literature: whereas SHELEME (1989: 33) translates usur-aan-ch-ú < usur- 'tie' as an instrument nominal 'rope used to tie something', HUDSON (1976: 273) views it as a patient nominal 'prisoner' (i.e. someone who is tied).

18 Instruments usually function as oblique objects (encoded in the ICP case). Less frequently, they occur as subjects of activity verbs, for instance: káltunku weesesí xaphá murrodáa [...] 'and if the hatchet (SUBJECT) cuts the roots of the enset plant [...]' (K8: 31).

19 See type (ii) patient nominals in the women's avoidance vocabulary (3.5.)

20 This term is adopted from PANAGL (1978: 455). 
Informants questioned about the semantics of various -aan derivates often allow an agentive interpretation in addition to an established instrumental or locative interpretation. Note, for instance, gamax-aan-ch-ú < gamax- 'sharpen' (i) 'instrument used to sharpen' and (ii) 'person who sharpens'; shiinsh-aan-ch-ú < shiinsh- 'wipe' (i) 'piece of cloth used to wipe' and (ii) 'person who wipes'; xaaf-aan-ch-ú $<$ xaaf'write' (i) 'instrument used to write' and (ii) 'person who writes'. A place nominal such as afuushsh-aan-ch-ú < afuushsh- 'put, place', which is attested as a spontaneously coined translation of 'shelf' (place on which, e.g., books are put) and of 'saucer' (device on which a cup is put), is also considered appropriate to refer to a "putter", i.e. a person who puts something somewhere, if a suitable context is provided (working in a warehouse, the "putter" is responsible for putting goods at their proper places).

Certain interpretations are ruled out by synonym restrictions (DRESSLER 1980: 113). This means that the existence of an established agent, instrument, patient, or place nominal makes one logically possible interpretation of a deverbal -aan derivate highly unlikely, though not necessarily ungrammatical. In the case of nuggussaan-ch-ú PATIENT 'circumcised' (< nugguss- 'circumcise'), for instance, agent-patient ambiguities are excluded, because the circumciser (the agent) is called falmaan-ch-ú(-ta). ${ }^{21}$ The derivate kit-aan-ch-ú < kit- 'filter' is preferably (though not exclusively) interpreted as agent nominal ('person who filters'), probably due to the existence of the established underived noun wonsh-ú-ta 'filter' for the filtering instrument.

Interestingly, -aan derivates based on non-extended verb stems (i.e. verb stems without the passive morpheme -am) are not easily accessible to a patient interpretation. Supplementing the database with elicited patient nominal examples turned out to be an almost impossible task. Informants rejected, for instance, the interpretation of kit-aan-ch-ú < kit- 'filter' as referring to 'something which is (to be) filtered' or xaaf-aan-ch-ú < xaaf- 'write' as referring to 'something which is (to be) written'. ${ }^{22}$

Though Kambaata has various mechanisms which create deverbal agents, instruments, places and patients, only one of them can be considered a "rival" of the -aan derivation. Patient nouns ${ }^{23}$ are formed by the -an-ch-á derivation (see aassan-ch-á 'gift' < aass- 'give', qoocc-an-ch-á 'creature; creation' < qoocc- 'create'). The high productivity of the -an-ch-á pattern might be one reason for the restricted application of the morpheme -aan for the derivation of patient nominals.

The derivation of instruments, agents, patients, and places from verb stems by other patterns (e.g. -im-á for instruments) is not productive and instead highly lexicalized. The semantic widening of the -aan derivation might have been facilitated by the unproductivity of other derivational morphemes.

21 The base of this derivate is unknown to me

22 PANTHER \& THORNBURG (2003: 286) and RYDER (1999: 284-90) discuss possible conceptual reasons why patient interpretations are less productive than agentive and instrumental ones.

23 The -an-ch-á derivation also generates action nouns (Treis 2008: 158f). 


\subsection{Neologisms and Avoidance Terms}

The productivity of the deverbal -aan derivation is reflected in the avoidance vocabulary of Kambaata women (TREIS 2005). In order to show respect towards their in-laws, married women of the old days had to avoid all words starting with the same syllable as the names of their father and mother-in-law. They substituted tabooed words with lexical doublets (ballishsha terms), synonyms, periphrases, antonyms etc. Another spontaneously applicable strategy was the production of substitutes with the help of the -aan derivation (35). The -aan derivates of the avoidance vocabulary refer to agents, instruments, patients and places.

(35) harruuchchú 'donkey' $\rightarrow$ iyy-aan-ch-ú AGENT $<$ iyy- 'carry ${ }^{, 24}$

handarchúta 'dove' $\rightarrow$ kuukees-aan-ch-ú-ta AGENT < kuukees- 'coo'

abbaasimá 'broom' $\rightarrow$ sháaqq a'-aan-ch-ú INSTR < sháaqq a'- 'sweep (a small place) clean'

koorú 'saddle' $\rightarrow$ saa'll-aan-ch-ú INSTR < saa 'll- 'ride'

gaayyáta 'water pipe' $\rightarrow$ ag-aan-ch-ú-ta PATIENT < ag- 'drink; smoke'

bahá 'artificial calf ${ }^{25} \rightarrow$ laax-aan-ch-ú PATIENT < laax- 'lick'

meetá 'scraping board' $\rightarrow$ zuug-aan-ch-ú PLACE $<$ zuug- 'scrape'

woqqáa 'road' $\rightarrow$ maram-aan-ch-ú PLACE $<$ maram- 'walk'

The -aan derivation is also applied to create neologisms in the common language, e.g. ga"-isiis-aan-ch-ú-ta 'vowel' [lit. "one that causes to call"] (KXS: 1), ga"-amaan-ch-ú-ta 'consonant' [lit. "one that is called"] (KXS: 4) and aphph-an-siisaanchú 'conjunction' [lit. "one that causes to join each other"]. It is spontaneously used to name devices which have no Kambaata translations: an informant describing a picture with a coat hook, for instance, termed this uncommon instrument sa'nniis-aan-ch-ú lit. "one that causes to hang".

\subsection{Denominal Derivates}

All attested denominal examples, apart from mooc-in-aan-ch-ú-ta (30), refer to human referents. They can be paraphrased as 'someone who is habitually occupied with N' (36), 'someone who makes use of N' (37), 'someone who has N' (38). ${ }^{26}$

(36) zeem-aan-ch-ú 'shepherd' < zeem-á-ta 'herding, 27

(37) lokk-aan-ch-ú 'pedestrian' (L52: 351) < lokk-á-ta 'foot'

(38) sal-aan-ch-ú-ta 'pregnant woman' < sal-áa 'foetus' shishir-aan-ch-ú 'leper (final stage)' < shishir-á 'leprosy (final stage)'

24 The arrow $\rightarrow$ is to be read as "is substituted by".

25 An artificial calf stimulates the milk production of a cow whose calf has died and who is given instead a bahá to lick.

26 There are also some possible denominal -aan derivates in the Burji dictionary, e.g. bokk-aancoo 'mad person' (< bokk-ee 'madness') and labb-aancoo 'liar' (< labb-ee 'lie (n)') (ROBA DAME \& WEDEKIND 2008: 9, 55). Burji even seems to have a de-ideophonic -aan derivate lukk-aancoo 'hen, chicken' (<lukku 'go away! (addressed to fowl)' (ROBA DAME \& WEDEKIND 2008: 57).

27 Unlike in Alaaba (SCHNEIDER-BLUM 2007: 147), a verb zeem- 'herd' does not exist in Kambaata; there is, however, a verb ze'- 'herd'. 
The restricted productivity of denominal -aan derivates can be attributed to the high productivity of a competing derivational pattern. On the basis of nouns, the -aam [!] derivation creates nominals with the meaning '(one) that has $\mathrm{N}$, is full of $\mathrm{N}$, is characterized by N'. A comparison of the -aan derivates in (38) and selected -aam derivates in (39) shows that there is a considerable functional overlap for these derivational patterns.

(39) hoofichch-aam-ú '(one) that has a goitre' < hoofichch-ú 'goitre' hangaar-aam- $\dot{u}$ '(one) that has a skin disease' < hangaar- $u$ 'skin disease' $x o o b b-e$ '-aam- $u$ ' (one) that suffers from elephantiasis' < xoobb-ita 'elephantiasis'

\section{Conclusion}

The HEC languages share a cognate morpheme -aan which derives agent nouns (or adjectives) from verbs. In some HEC languages (Gedeo and Hadiyya), the -aan derivates do not seem to designate anything other than agents and experiencers (HUDSON 1976: 273). However, agent-experiencer-instrument-place polysemy is a feature of the -aan derivation in Alaaba, K'abeena and Sidaama. In Kambaata, the -aan derivation also generates patient nominals (3.3) in addition to agent, experiencer (3.1), instrument and place nominals (3.2). ${ }^{28}$ The impression that the polysemy of -aan derivates is most pronounced in Kambaata, but less elaborate in other HEC languages, is very likely attributable to the unequal state of documentation and the little data that we have on this derivational mechanism in other HEC languages. While the agent/experiencer and instrument nominals derived by -aan are widespread in all types of language data in Kambaata, a significant amount of place nominals and patient nominals can only be found in a corpus of procedural texts. It is, therefore, quite possible that a more elaborate polysemy of the agentive derivation will be detected in future works on still insufficiently documented HEC languages.

$\begin{array}{ll}\text { Abbreviations } & \\ 1 / 2 / 3 & 1^{\text {st }} / 2^{\text {nd }} / 3^{\text {rd }} \text { person } \\ \text { A } & \text { adjective } \\ \text { AAN } & \text { agentive derivation } \\ \text { ABL } & \text { ablative } \\ \text { ACC } & \text { accusative } \\ \text { ADV } & \text { adverbializer } \\ \text { DAT } & \text { dative } \\ \text { F } & \text { feminine } \\ \text { GEN } & \text { genitive } \\ \text { H89 } & \text { HuDSON }(1989)\end{array}$

28 The same is possibly true for Burji, as far as one can tell from some entries ending in -aan-coo in the Burji dictionary (RoBA DAME \& WEDEKIND 2008). 
HEC

Highland East Cushitic (Hadiyya, Libido, Kambaata, Alaaba, K'abeena, Sidaama, Gedeo and Burji)

ICP instrumental-comitative-perlative

IPV imperfective

KXS MAATEWOOS (1992)

K1-K8 KAMBAATISSATA (1989)

L52 LESLAU (1952)

M masculine

MID middle

$\mathrm{N}$ noun

NOM nominative

OBL oblique

PASS passive

PCO perfective converb

PL plural, plurative

PVE perfective with -e

REL relative

S89 SHELEME (1989)

SG singular, singulative

$\mathrm{V}$ verb

\section{References}

AnBessa TeFERra (2000): A Grammar of Sidaama. Ph.D. Thesis, Hebrew University of Jerusalem. Berhanu Mathewos (1986): An Analysis of Kambata Proverbs. M.A. Thesis, Addis Ababa University.

BORELLI, JULES (1890): Ethiopie méridionale. Journal de mon voyage aux pays Amhara, Oromo et Sidama (septembre 1885 à novembre 1888). Paris: Quantin.

Cerulli, EnRICO (1925): Note su alcune popolazioni Sidama dell'Abissinia meridionale, in: Rivista Studi Orientali (sc. mor.) 10, 647-663.

Crass, JoAChim (2005): Das K'abeena. Deskriptive Grammatik einer hochlandostkuschitischen Sprache. Köln: Köppe.

DRESSLER, WOLFGANG U. (1980): Universalien von Agens-Wortbildungen, in: BRETSCHNEIDER, GUNTER \& LehmanN, CHRISTIAN (eds.), Wege zur Universalienforschung. Sprachwissenschaftliche Beiträge zum 60. Geburtstag von Hansjakob Seiler. Tübingen: Narr, 110-114.

DRESSLER, WolfGANG U. (1986): Explanation in Natural Morphology. Illustrated with Comparative and Agent-noun Formation, in: Linguistics 24, 519-548.

Hudson, Grover (1976): Highland East Cushitic, in: Bender, M. Lionel (ed.), The Non-Semitic Languages of Ethiopia. East Lansing, MI: African Studies Center, Michigan State University, 232-277.

Hudson, Grover (1989): Highland East Cushitic Dictionary. Hamburg: Buske.

KambaAtissata. RosaAnchi MaXaAfa [Kambaata Language. School Book] (1989 E.C.): Grade 1-8. Southern Nations Nationalities and Peoples Regional State: Education Bureau.

Kane, Thomas LeIPER (1990): Amharic-English Dictionary. Vol. 1. Wiesbaden: Harrassowitz.

KaWACHI, KazUHIRO (2007): A Grammar of Sidaama (Sidamo), a Cushitic Language of Ethiopia. Ph.D. Thesis, University at Buffalo, State University of New York.

LeSLaU, Wolf (1952): Notes on Kambatta of Southern Ethiopia, in: Africa 22, 348-359.

Leslau, Wolf (1956): Additional Notes on Kambatta of Southern Ethiopia, in: Anthropos 51, $985-$ 993.

MaAtewoos Shagana (1992 E.C.): Kambaatissa Xifati Seerrata. Ed. by LiIRAnSo Wotango \& Titoon HeEgana. Duuraame: Educational Department of the Kambaata-Alaaba-Xambaaro Zone.

Malchukov, Andrej L. (2000): Dependency Reversal in Noun-Attributive Constructions: Towards a Typology. Munich: Lincom Europa. 
Moreno, Martino M. (1939): Appunti di Cambatta e di Alaba, in: Rendiconti della Reale Accademia dei Lincei 14, 269-279.

PANAGL, Oswald (1978): Agens und Instrument in der Wortbildung, in: Dressler, WolfGang U. \& Meid, Wolfgang (eds.), Proceedings of the 12th International Congress of Lingistics. Vienna, Aug 28 - Sept 2, 1977. Innsbruck: Institut für Sprachwissenschaft, Universität Innsbruck, 453-456.

Panther, Klaus-Uwe \& Thornburg, Linda L. (2003): The Roles of Metaphor and Metonymy in English -er nominals, in: DiRven, RenÉ \& PÖRINGS, RALF (eds.), Metaphor and Metonymy in Comparison and Contrast. Berlin, New York: Mouton de Gruyter, 279-319.

Roba dame \& Wedekind, Charlotte (2008). Burji Dictionary (Revision of the 2004 Version). Available online at: http://www.kwedekind.de/Eingang1/Biblio1.htm (Date of access: 2 June 2010).

RYDER, MARY ELLEN (1999): Bankers and Blue-chippers: An Account of -er Formations in Presentday English, in: English Language and Linguistics 3, 269-297.

SCHNEIDER-Blum, GerTRUD (2007): A Grammar of Alaaba. A Highland East Cushitic Language of Ethiopia. Cologne: Köppe.

Sheleme KitATA (1989): Noun Morphology of Kambata. B.A. Thesis, Addis Ababa University.

Treis, Yvonne (2005): Avoiding Their Names, Avoiding Their Eyes. How Kambaata Women Respect Their In-laws, in: Anthropological Linguistics 47, 3, 292-320.

Treis, Yvonne (2008): A Grammar of Kambaata (Ethiopia). Part 1: Phonology, Nominal Morphology, and Non-verbal Predication. Cologne: Köppe.

YVONNE TREIS

Research Centre for Linguistic Typology

La Trobe University

Victoria 3086, Australia

y.treis@latrobe.edu.au 